\title{
Debt Financing dan Dampaknya terhadap Perkembangan Usaha Mikro di Bogor
}

\section{Debt Financing and It's Impact on the Development of Micro Enterprises in Bogor}

\author{
Jaenal Effendi ${ }^{1}$, Ditta Wardani ${ }^{2}$ \\ ${ }^{1}$ Institut Pertanian Bogor, jaenfendi@gmail.com \\ ${ }^{2}$ Institut Pertanian Bogor, dittawardhani10@gmail.com
}

\begin{abstract}
Micro and small enterprises (MSEs) have an important role in supporting the national economy. Nevertheless, MSEs still have a major problem in its development, called limited capital. The presence of BPRS which is part of sharia financial institutions is expected to provide financing assistance for MSEs. The financing provided by BPRS is not only given in the form of equity financing but also in the form of debt financing. This study analyzes the effect of debt financing on MSEs development and also the factors influenceing the income and profit of MSEs after getting debt financing. The method used in this research is paired sample $t$ test and Ordinary Least Square (OLS). The result of paired sample t test showed that the variable of earnings and profit of MSEs have significant change after getting financing. Furthermore, the result of analysis with OLS method showed that labor variable, amount of financing, profit rate, gender dummy, and education dummy have a significant effect to earnings and profit of MSEs
\end{abstract}

Key words: BPRS, Debt Financing, OLS, Paired sample t-test, Micro and Small Entreprises

\begin{abstract}
Abstrak. Usaha mikro dan kecil (UMK) memiliki peran penting dalam mendukung perekonomian nasional. Meskipun demikian, UMK masih memiliki permasalahan utama dalam pengembangannya, yaitu keterbatasan modal. Hadirnya BPRS yang merupakan bagian dari lembaga keuangan syariah diharapkan dapat memberikan bantuan pembiayaan bagi UMK. Pembiayaan yang diberikan oleh BPRS tidak hanya diberikan dalam bentuk equity financing tapi juga dalam bentuk debt financing. Penelitian ini menganalisis pengaruh pembiayaan kategori debt financing terhadap perkembangan UMK dan menganalisis faktor-faktor yang memengaruhi pendapatan dan keuntungan UMK setelah mendapatkan debt financing. Metode yang digunakan dalam penelitian ini adalah paired sample t test (uji t berpasangan) dan Ordinary Least Square (OLS). Hasil uji $\mathrm{t}$ berpasangan menunjukkan bahwa variabel pendapatan dan keuntungan UMK mengalami perubahan yang signifikan setelah mendapatkan pembiayaan. Selanjutnya, hasil analisis dengan metode OLS menunjukkan bahwa variabel tenaga kerja, jumlah pembiayaan, tingkat
\end{abstract}


keuntungan, dummy jenis kelamin, dan dummy pendidikan berpengaruh signifikan terhadap pendapatan dan keuntungan UMK.

Kata kunci: BPRS, Debt Financing, OLS, Uji-t berpasangan, Usaha Mikro Kecil

\section{Pendahuluan}

Kekuatan perekonomian Indonesia tidak terlepas dari peran serta Usaha Mikro, Kecil, dan Menengah (UMKM). Berdasarkan data Kementrian Koperasi dan Usaha Kecil Menengah, jumlah UMKM pada tahun 2015 mencapai pangsa $99.99 \%$ dari total keseluruhan unit usaha di Indonesia dengan jumlah sebesar 59.26 juta unit usaha. Sektor UMKM menjadi unit usaha penyerap tenaga kerja sebanyak 123.33 juta orang (KEMENKOP 2015). Jika di persentasekan $96.71 \%$ tenaga kerja yang tersedia telah diserap oleh sektor ini. Penyerapan jumlah tenaga kerja yang tinggi tersebut menunjukkan bahwa UMKM mampu menciptakan lapangan pekerjaan bagi masyarakat dan mengurangi angka pengangguran. Angka pengangguran yang berkurang tentunya akan berdampak pada peningkatan pendapatan dan kesejahteraan masyarakat. Di sisi lain UMKM menyumbang kontribusi yang cukup besar terhadap Produk Domestik Bruto (PDB). Hal ini dibuktikan dari data yang dirilis oleh Kementrian Koperasi dan Usaha Kecil Menengah bahwa pada tahun 2015, sektor UMKM berkontribusi sebesar IDR 1.655 triliun terhadap PDB negara.

Usaha Mikro Kecil (UMK) merupakan skala usaha yang memiliki penghasilan pertahun tidak lebih dari IDR 300 juta berdasarkan UndangUndang Nomor 20 Tahun 1998. Unit usaha ini lebih mendominasi jika dibandingkan dengan usaha menengah, hal ini dikarenakan UMK tersebar di seluruh wilayah termasuk pedesaan, sehingga UMK memiliki potensi yang lebih besar jika dibandingkan dengan usaha menengah (Tambunan 2009). Potensi UMK yang cukup besar tidak mudah untuk dikembangkan. Hal ini dikarenakan adanya beberapa kendala dan permasalahan. Permasalahan utama yang dihadapi oleh pelaku UMK yaitu keterbatasan modal. Sebagian besar pelaku UMK yang berlokasi di pedalaman atau pedesaan tidak pernah mendapat kredit dari bank atau lembaga keuangan lainnya, meskipun telah banyak skim kredit khusus bagi pengusaha kecil. Pelaku UMK dianggap unbankable oleh lembaga keuangan karena kemampuan mengembalikan pinjamannya rendah dan tidak memiliki 
agunan, sehingga hanya mengandalkan modal yang mereka miliki (Muhammad 2005).

Kehadiran perbankan syariah diharapkan dapat menjadi suatu altenatif solusi atas keterbatasan permodalan yang dihadapi oleh UMK, karena pada dasarnya perbankan syariah memiliki perhatian khusus terhadap pengembangan sektor riil. Selain itu pembiayaan yang dilakukan oleh perbankan syariah tidak menerapkan sistem bunga, sehingga tidak membebani nasabah. Nilai-nilai kebersamaan, kemitraan, kesinambungan, keadilan dan lepasnya salah satu pihak dari beban untuk membayar modal dan bunga secara berkesinambungan menjadi kekuatan tersendiri yang tidak dimiliki oleh lembaga-lembaga keuangan konvensional.

Perkembangan industri keuangan syariah yang cukup pesat berkorelasi positif terhadap bertambahnya jumlah perbankan syariah di Indonesia. Hal ini ditunjukkan pada Tabel 1 yang memperlihatkan bahwa terjadi peningkatan jumlah Bank Umum Syariah (BUS) pada tahun 2010 berjumlah 11 unit bertambah menjadi 13 unit di tahun 2016. Begitu pula dengan jumlah Bank Pembiayaan Rakyat Syariah (BPRS) yang selalu mengalami peningkatan dari tahun ke tahun hingga mencapai jumlah 166 unit di tahun 2016. Di sisi lain jumlah Unit Usaha Syariah (UUS) cenderung mengalami penurunan menjadi 21 unit di tahun 2016, hal ini dikarenakan adanya spin off UUS menjadi BUS.

Tabel 1 Perkembangan jumlah BUS, UUS, dan BPRS periode 20102016

\begin{tabular}{cccccccc}
\hline \multirow{2}{*}{ Jenis } & \multicolumn{7}{c}{ Tahun } \\
\cline { 2 - 9 } & 2010 & 2011 & 2012 & 2013 & 2014 & 2015 & 2016 \\
\hline BUS & 11 & 11 & 11 & 11 & 12 & 12 & 13 \\
\hline UUS & 23 & 24 & 24 & 23 & 22 & 22 & 21 \\
\hline BPRS & 150 & 155 & 158 & 160 & 163 & 163 & 166 \\
\hline
\end{tabular}

Sumber : Statistik Perbankan Syariah

Pada Tabel 1 memperlihatkan bahwa BPRS memiliki jumlah yang cukup banyak jika dibandingkan dengan UUS dan BUS. Selain memiliki jumlah yang cukup banyak, lokasi BPRS yang tersebar diberbagai wilayah di Indonesia, dianggap mampu menjangkau pelaku UMK yang mayoritas berada di wilayah pedesaan, sehingga kehadiran BPRS ini diharapkan akan 
membantu para pelaku UMK dalam menghadapi masalah keterbatasan modal.

Penyaluran pembiayaan yang dilakukan oleh BPRS terbagi menjadi dua bentuk, yaitu equity financing dan debt financing (Dewi 2007). Equity financing merupakan penyaluran dana berdasarkan pada prinsip bagi hasil. Jenis pembiayaan ini biasanya menggunakan akad mudharabah dan musyarakah dalam implementasinya. Sementara debt financing merupakan pembiayaan berdasarkan prinsip jual beli yang biasanya menggunakan akad murabahah, salam, istishna dan ijarah.

Komposisi pembiayaan BPRS seperti pada Gambar 1 menunjukkan bahwa sejak tahun 2012 hingga 2015 jumlah pembiayaan kategori debt financing dan equity financing mengalami peningkatan, namun jumlah debt financing jauh lebih besar dibandingkan equity financing. Hal ini disebabkan karena debt financing memiliki tingkat risiko yang lebih kecil, karena adanya jaminan dan margin keuntungan yang telah ditetapkan sebelumnya berdasarkan kesepakatan pihak bank dan nasabah, sehingga debt financing lebih diminati oleh bank dibandingkan dengan pembiayaan equity financing. Selain itu debt financing saat ini tidak hanya digunakan untuk membiayai sektor konsumtif melainkan juga pada sektor produktif, meskipun secara normatif pembiayaan yang seharusnya digunakan untuk modal kerja adalah equity financing.

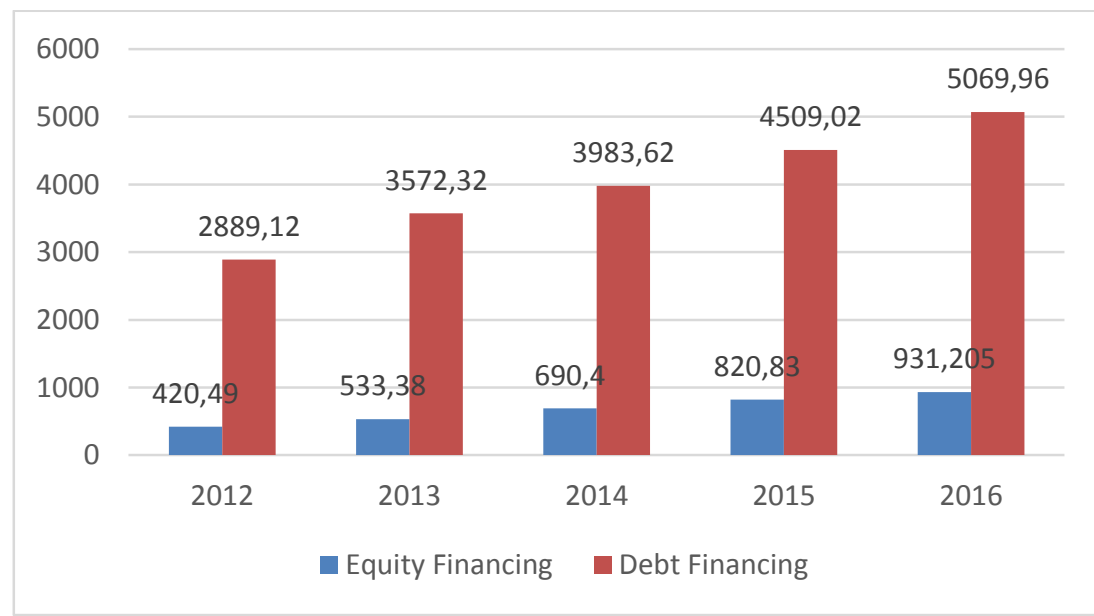

Sumber : Statistik Perbankan Syariah, 2017 (diolah)

Gambar 1 Komposisi pembiayaan BPRS tahun 2012-2017

Jurnal Al-Muzara'ah Vol.4, No.2, 2016

(ISSN p: 2337-6333; e: 2355-4363) 
Pembiayaan yang umumnya diberikan sebagai modal kerja bagi pelaku usaha adalah pembiayaan yang termasuk dalam kategori equity financing. Akan tetapi saat ini pembiayaan kategori debt financing juga digunakan dalam sektor produktif dan jumlah pembiayaannya lebih besar dibandingkan pembiayaan kategori equity financing. BPRS Amanah Ummah merupakan BPRS terbesar di wilayah Bogor yang memberikan pembiayaan dengan kategori debt financing bagi pelaku UMK. Jumlah pembiayaan kategori debt financing yang diberikan BPRS Amanah Ummah selalu meningkat setiap tahunnya dengan jumlah yang lebih besar dibandingkan pembiayaan equity financing. Pada tahun 2014 jumlah pembiayaan kategori debt financing yang diberikan BPRS Amanah Ummah sebesar IDR 114.40 miliar dan pada tahun 2015 jumlahnya meningkat menjadi IDR 127.57 miliar. Sementara itu jumlah pembiayaan equity financing pada tahun 2014 dan 2015 masing-masing hanya sebesar IDR 0.51 miliar dan IDR 4.61 miliar. Pada Tabel 2 terlihat bahwa kelompok pertukaran barang dengan uang pada pembiayaan debt financing memiliki persentase lebih besar jika dibandingkan pertukaran uang dengan barang, yaitu $99.13 \%$.

Komposisi pertukaran barang dan uang yang lebih besar menunjukkan bahwa pada BPRS Amanah Ummah jumlah pembiayaan murabahah dan ijarah lebih banyak dibandingkan pembiayaan salam dan istishna. Pembiayaan murabahah merupakan pembiayaan dengan resiko terendah, karena return yang didapat dari pembiayaan murabahah sudah dapat ditentukan nilainya dan diperbolehkan adanya jaminan (Khan \& Ahmed 2001). Rachman (2014) juga menyatakan bahwa pembiayaan murabahah dianggap cukup fleksibel dalam membangun usaha mikro.

Pembiayaan debt financing khususnya pembiayaan murabahah dan ijarah yang jumlahnya cukup besar apabila dijalankan sesuai dengan prinsip syariah diharapkan akan mampu mengatasi masalah permodalan pada UMK serta dapat memberikan keuntungan bagi kedua belah pihak (nasabah dan pihak bank). Oleh karena itu tujuan dalam penelitian ini yaitu untuk mengetahui pengaruh debt financing terhadap perkembangan UMK dan menganalisis faktor yang memengaruhi pendapatan dan keuntungan UMK setelah mendapatkan debt financing khususnya pembiayaan murabahah dan ijarah. 
Tabel 2 Komposisi pembiayaan debt financing BPRS Amanah Ummah

\begin{tabular}{|c|c|c|c|c|c|c|}
\hline $\begin{array}{l}\text { Debt } \\
\text { Financing }\end{array}$ & $\begin{array}{c}2013 \\
\text { Total } \\
(\mathrm{Rp} \\
\text { Miliar) }\end{array}$ & $(\%)$ & $\begin{array}{c}2014 \\
\text { Total } \\
\text { (Rp Miliar) }\end{array}$ & $(\%)$ & $\begin{array}{c}2015 \\
\text { Total } \\
\text { (Rp } \\
\text { Miliar) }\end{array}$ & $(\%)$ \\
\hline $\begin{array}{l}\text { Barang- } \\
\text { uang } \\
\text { (murabaha } \\
h \text { dan } \\
\text { ijarah) }\end{array}$ & 91,32 & 97,84 & 112,45 & 98,30 & 126,47 & 99,1 \\
\hline $\begin{array}{l}\text { Uang- } \\
\text { barang } \\
\text { (salam dan } \\
\text { istishna) }\end{array}$ & 2,01 & 2,16 & 1,95 & 1,70 & 1,10 & 0,87 \\
\hline Jumlah & 93,33 & 100 & 114,40 & 100 & 127,57 & 100 \\
\hline
\end{tabular}

\section{Tinjauan Pustaka}

Bank Pembiayaan Rakyat Syariah (BPRS) merupakan salah satu jenis lembaga keuangan perbankan syariah yang beroperasi mengikuti prinsip syariah. Berdirinya Bank Pembiayaan Rakyat Syariah (BPRS) didasarkan pada UU No. 7 Tahun 1992 tentang Perbankan dan Peraturan Pemerintah (PP) No. 72 Tahun 1992 tentang Bank berdasarkan Prinsip Bagi Hasil. Selanjutnya dalam UU Nomor 21 Tahun 2008 tentang Perbankan Syariah disebutkan bahwa Bank Pembiayaan Syariah (BPRS) adalah bank syariah yang dalam kegiatannya tidak memberikan jasa dalam lalu lintas pembayaran.

Pembiayaan menurut Undang-Undang No 21 Tahun 2008 yaitu penyediaan dana atau tagihan yang dipersamakan dengan itu berupa transaksi bagi hasil, transaksi sewa-menyewa, transaksi jual beli, atau transaksi pinjam meminjam dalam bentuk piutang berdasarkan persetujuan atau kesepakatan antara bank dan pihak lain yang mewajibkan pihak yang dibiayai atau diberi fasilitas dana untuk mengembalikan dana tersebut setelah jangka waktu tertentu dengan imbalan ujrah, tanpa imbalan, atau bagi hasil. Pembiayaan pada perbankan syariah dapat dikategorikan menjadi dua, yaitu equity financing dan debt financing. 
Debt financing merupakan pembiayaan atau penyaluran dana berdasarkan prinsip jual beli. Dalam operasional perbankan syariah pembiayaan debt financing terbagi dalam dua objek, yaitu pertukaran barang dengan uang dan pertukaran uang dengan barang (Dewi 2007). Objek pertukaran barang dengan uang terdiri dari dua jenis pembiayaan yatu, murabahah dan ijarah. Sementara objek pertukaran uang dengan barang terdiri pembiayaan salam dan istishna. Murabahah merupakan transaksi jual beli dimana objek jual beli dijual dengan harga pokok pembelian ditambah dengan tambahan keuntungan yang diinginkan, sedangkan ijarah adalah transaksi pemindahan hak guna atas barang atau jasa dalam waktu tertentu dengan pembayaran upah tanpa disertai pemindahan hak kepemilikan barang (Zuhaily 2001).

Secara bahasa murabahah berasal dari Bahasa Arab, yaitu al-ribh yang bermakna tumbuh dan berkembang (Nawawi 2012). Zuhaily (2001) menjelaskan murabahah merupakan transaksi jual beli dimana objek jual beli dijual dengan harga pokok pembelian ditambah dengan tambahan keuntungan yang diinginkan. Selain itu dalam murabahah penjual harus menginformasikan kepada pembeli tentang harga pokok pembelian dan tingkat keuntungan yang diambil. Murabahah dalam dunia perbankan, yaitu jual beli barang menggunakan harga asal dengan tambahan keuntungan yang disepakati oleh pihak bank dan nasabah. Pada awalnya murabahah merupakan konsep jual beli yang tidak ada hubungannya dengan pembiayaan, namun bentuk jual beli ini kemudian digunakan oleh perbankan syariah dengan menambahkan beberapa konsep lain sehingga menjadi bentuk pembiayaan (Ascarya 2008). Dalam pembiayaan ini, bank sebagai pemilik dana membelikan barang sesuai dengan spesifikasi yang diinginkan oleh nasabah yang membutuhkan pembiayaan, kemudian menjualnya ke nasabah tersebut dengan penambahan keuntungan tetap. Sementara itu, nasabah dapat mengembalikan hutangnya di kemudian hari secara tunai maupun cicilan. Dalam akad murabahah terdapat beberapa unsur, seperti transparansi dan kejujuran sehingga melahirkan saling percaya antara penjual dan pembeli (Hakim 2011). Pembiayaan murabahah juga diatur dalam Fatwa Dewan Syariah Nasional Nomor 04/DSNMUI/IV/2000 tentang murabahah.

Secara etimologis al-ijarah berasal dari kata al-ajru yang artinya ganti, upah atau menjual manfaat (Nawawi 2012). Zuhaily (2001) menjelaskan pengertian ijarah adalah transaksi pemindahan hak guna atas barang atau jasa dalam waktu tertentu dengan pembayaran upah tanpa disertai 
pemindahan hak kepemilikan barang. Ijarah dapat dipakai sebagai bentuk pembiayaan, walaupun pada mulanya bukan merupakan bentuk pembiayaan tetapi bagian dari aktivitas usaha seperti jual beli (Ascarya 2008). Individu yang membutuhkan pembiayaan untuk membeli aset dapat mendatangi pemilik dana (bank) untuk membiayai pembelian aset produktif. Selanjutnya pemilik dana membeli barang yang dimaksud dan kemudian menyewakannya kepada yang membutuhkan aset tersebut. Beberapa syarat yang harus dipenuhi dalam penggunaan ijarah sebagai bentuk pembiayaan, antara lain jasa atau manfaat yang akan diberikan oleh aset yang disewakan tersebut harus tertentu dan diketahui dengan jelas oleh kedua belah pihak; kepemilikan aset dan tanggung jawab pemeliharaan tetap pada yang menyewakan; akad ijarah dihentikan pada saat aset yang bersangkutan berhenti memberikan manfaat kepada penyewa; aset tidak boleh dijual kepada penyewa dengan harga yang ditetapkan sebelumnya, karena penetapan harga terhadap aset yang ingin dijual ditentukan pada saat kontrak berakhir. Syarat-syarat tersebut menyiratkan bahwa pemilik aset tidak memperoleh keuntungan tertentu yang ditetapkan sebelumnya, akan tetapi tingkat keuntungan baru diketahui setelahnya. Pembiayaan ijarah diatur dalam Fatwa Dewan Syariah Nasional Nomor 09/DSNMUI/IV/2000 tentang ijarah. Menyediakan aset yang disewakan.

Pembiayaan ijarah terbukti berpengaruh positif terhadap perkembangan. UMKM dan faktor-faktor yang memengaruhi perubahan omzet dan keuntungan UMKM setelah menerima pembiayaan ijarah adalah frekuensi pembiayaan, modal usaha, tenaga kerja, dan dummy pendidikan (Salamah 2015). Selanjutnya studi terkait dampak pembiayaan syariah terhadap profitabilitas usaha mikro membuktikan bahwa pembiayaan dengan akad murabahah dan qardhul hasan berpengaruh positif terhadap profitabilitas usaha mikro (Rachman 2014).

Anggraeni et al. (2015) dalam penelitiannya tentang Akses UMKM terhadap Pembiayaan Mikro Syariah dan Dampaknya terhadap Perkembangan Usaha, mengemukakan bahwa faktor yang memengaruhi akses UMKM terhadap pembiayaan mikro syariah dari BMT adalah variabel dummy akses simpanan, umur, dummy jenis usaha manufaktur dan omset usaha. Selain itu pembiayaan syariah dari BMT terbukti memberikan dampak positif terhadap perkembangan dan faktor-faktor yang memengaruhinya antara lain lama pendidikan, lama usaha, besar pembiayaan, dan besarnya kredit konvensional. Selain itu Ahiawodzi dan Adade (2012) melakukan riset tentang Pengaruh Akses Kredit dan 
Pertumbuhan Usaha Kecil dan Menengah di Kota Ho, Ghana. Hasil penelitian tersebut menunjukkan bahwa variabel akses terhadap kredit, modal awal, total investasi, dan omset tahunan memiliki hubungan positif dengan pertumbuhan UKM dan memberikan kontribusi terhadap pertumbuhan UKM di Kota Ho.

Akoten et al. (2016) meneliti tentang Akses Kredit dan Dampaknya terhadap Usaha Mikro dan Kecil. Lama usaha berpengaruh positif terhadap akses kredit dari lembaga keuangan mikro. Faktor-faktor yang berpengaruh positif terhadap keuntungan usaha adalah lama usaha, pelatihan, dan dummy status pernikahan.

\section{Metode Penelitian}

Jenis data yang digunakan dalam penelitian ini terdiri dari data primer dan data sekunder. Data primer diperoleh dari hasil wawancara melalui penyebaran kuisioner dan wawancara langsung kepada pelaku UMK sektor perdagangan yang mendapatkan pembiayaan dengan kategori debt financing khususnya pembiayaan murabahah dan ijarah dari BPRS Amanah Ummah periode Desember 2014 hingga Desember 2015. Data sekunder diperoleh melalui dokumen dan laporan dari BPRS Amanah Ummah, Kementerian Koperasi dan Usaha Kecil Menengah, Bank Indonesia, Otoritas Jasa Keuangan, buku, jurnal, skripsi terkait serta sumber lainnya yang dapat membantu ketersediaan data.

Penelitian ini dilakukan di BPRS Amanah Ummah yang berlokasi di daerah Leuwiliang, Kabupaten Bogor. Pemilihan lokasi dilakukan secara purposive (kriteria tertentu) dengan pertimbangan bahwa BPRS Amanah Ummah merupakan BPRS terbesar di wilayah Bogor yang memberikan pembiayaan kategori debt financing bagi pelaku UMK. Pengambilan sampel dilakukan dengan menggunakan teknik non probability sampling (non acak) dengan teknik pengambilan data menggunakan metode purposive sampling. Populasi dalam penelitian ini adalah pelaku UMK sektor perdagangan yang mendapatkan pembiayaan untuk modal kerja dengan kategori debt financing khususnya pembiayaan murabahah dan ijarah dari BPRS Amanah Ummah. Total nasabah yang termasuk dalam populasi penelitian ini berjumlah 800 orang yang terdiri dari 780 responden pembiayaan murabahah dan 20 responden pembiayaan ijarah. Jumlah sampel ditentukan dengan menggunakan rumus slovin, sehingga sampel dalam penelitian ini berjumlah 90 responden yang terdiri dari 80 responden Jurnal Al-Muzara'ah Vol.4, No.2, 2016 
penerima pembiayaan murabahah dan 10 responden penerima pembiayaan ijarah.

\section{Uji t Berpasangan (Paired t test)}

Metode analisis data yang digunakan adalah metode uji t berpasangan. Uji $\mathrm{t}$ berpasangan (paired $t$ - test) merupakan salah satu metode pengujian hipotesis yang menggunakan data tidak bebas (berpasangan). Adapun yang dimaksud dengan data tidak bebas atau berpasangan yaitu objek penelitian dikenai dua perlakuan yang berbeda sehingga menghasilkan dua macam sampel dari perlakuan pertama dan kedua atau dengan kata lain data pada sampel kedua merupakan perubahan dari data sampel pertama (Kurniawan 2008).

Uji t berpasangan dalam penelitian ini digunakan untuk menganalisis pendapatan dan keuntungan pelaku UMK sebelum dan setelah mendapatkan pembiayaan dengan kategori debt financing khususnya pembiayaan murabahah dan ijarah. Uji-t berpasangan untuk pembiayaan kategori debt financing dapat dirumuskan sebagai berikut:

$$
t_{\text {hitung }}=\frac{\overline{\mathrm{d}}-\mu_{\mathrm{do}}}{\mathrm{s}_{\mathrm{d}} / \sqrt{\mathrm{n}}}
$$

Keterangan:

$\mathrm{t} \quad=\mathrm{t}$ statistik

$\bar{d} \quad=$ Rataan selisih pendapatan dan keuntungan setelah memperoleh pembiayaan kategori debt financing

$\mu_{\mathrm{do}} \quad=$ Rataan selisih populasi

$\mathrm{S}_{\mathrm{d}} \quad=$ Standar deviasi rataan selisih

$\mathrm{n} \quad=$ Banyaknya sampel penelitian

Hipotesis

H0 : $\mu$ setelah $=\mu$ sebelum

H1 : $\mu$ setelah $>\mu$ sebelum

\section{Ordinary Least Square (OLS)}

Analisis regresi berganda atau OLS merupakan teknik analisis data dalam membahas hubungan antara variabel terikat dengan variabel bebas. Dalam penelitian ini, metode OLS digunakan untuk menganalisis faktor-faktor Jurnal Al-Muzara'ah Vol.4, No.2, 2016 
yang memengaruhi pendapatan dan keuntungan UMK setelah mendapatkan pembiayaan kategori debt financing khususnya pembiayaan murabahah dan ijarah. Menurut Juanda (2009) ada beberapa asumsi yang harus dipenuhi dalam penggunaan model ini, di antaranya yaitu data harus menyebar normal, tidak ada hubungan linier sempurna antar peubah bebas(multikolinieritas), tidak ada korelasi antar sisaan (autokorelasi), nilai ragam konstan (homoskedastisitas). Berikut model OLS dalam penelitian ini:

$$
\begin{aligned}
\ln Y_{i}= & b_{o}+b_{1} X_{1}+b_{2} X_{2}+b_{3} X_{3}+b_{4} X_{4}+b_{5} X_{5}+b_{6} X_{6}+b_{7} X_{7}+b_{8} D_{j k}+b_{9} D_{j u} \\
& +b_{10} D_{s p}+b_{11} D_{p}+b_{12} D_{s n}+e_{i}
\end{aligned}
$$

Keterangan:

$\ln Y_{1}=$ Pendapatan usaha (rupiah)

$\ln Y_{2}=$ Keuntungan usaha (rupiah)

$\mathrm{b}_{\mathrm{o}}=$ Intersep

$\mathrm{X}_{1}=$ Usia (tahun)

$\mathrm{X}_{2}=$ Tenaga kerja (orang)

$\mathrm{X}_{3}=$ Lama usaha (tahun)

$\mathrm{X}_{4}=$ Modal awal usaha (juta)

$\mathrm{X}_{5}=$ Jumlah pembiayaan (juta)

$\mathrm{X}_{6}=$ Tingkat keuntungan $(\%)$

$\mathrm{X}_{7}=$ Tanggungan Keluarga (orang)

$\mathrm{D}_{\mathrm{jk}} \quad=$ Dummy jenis kelamin $(1=$ laki-laki, $0=$ perempuan $)$

$\mathrm{D}_{\mathrm{ju}} \quad=$ Dummy jenis usaha $(1=$ sayur dan buah, $0=$ lainnya $)$

$\mathrm{D}_{\mathrm{sp}} \quad=$ Dummy skema pembiyaan $(1=$ murabahah, $0=\mathrm{ijarah})$

$\mathrm{D}_{\mathrm{p}} \quad=$ Dummy pendidikan $(1=0-9$ tahun, $0=$ lainnya $)$

$\mathrm{D}_{\mathrm{sn}}=$ Dummy status pernikahan $(1=$ menikah, $0=$ lainnya $)$

\section{Pembahasan}

\subsection{Pengaruh Pembiayaan Kategori Debt Financing terhadap Perkembangan UMK}

Pengaruh debt financing terhadap perkembangan UMK yang di-proxy pada pendapatan dan keuntungan dapat diketahui dengan analisis uji $\mathrm{t}$ berpasangan. Pembiayaan kategori debt financing yang diberikan kepada pelaku UMK terbukti memberikan pengaruh terhadap perkembangan UMK. Perkembangan UMK diukur melalui pendapatan dan keuntungan yang diperoleh setelah mendapatkan pembiayaan menggunakan uji $\mathrm{t}$ berpasangan. Hasil uji t berpasangan pada Tabel 4 menunjukkan bahwa 
rata-rata pendapatan dan keuntungan responden pembiayaan kategori debt financing mengalami perbedaan yang signifikan antara sebelum dan setelah mendapatkan pembiayaan. Variabel pendapatan menunjukkan bahwa ratarata pendapatan per hari responden setelah mendapatkan pembiayaan lebih besar dibandingkan sebelum mendapatkan pembiayaan dengan selisih sebesar Rp417.433,33. Sama halnya dengan variabel pendapatan,variabel keuntungan pun menunjukkan adanya peningkatan setelah memperoleh pembiayaan debt financing. Keuntungan per hari responden setelah mendapatkan pembiayaan lebih besar dibandingkan sebelum mendapatkan pembiayaan dengan selisih sebesar Rp135.580. Selain itu dari hasil uji t berpasangan diperoleh nilai probabilitas < taraf nyata, sehingga dapat disimpulkan bahwa rata-rata pendapatan dan rata-rata keuntungan responden setelah mendapatkan pembiayaan lebih besar dibandingkan sebelum pembiayaan dan signifikan pada taraf nyata $1 \%$.

Pembiayaan debt financing yang telah diberikan kepada para pelaku UMK akan meningkatkan modal pelaku UMK, sehingga UMK dapat berkembang lebih besar lagi. Lokasi usaha yang berada di pasar juga menjadi salah satu faktor pendukung dalam peningkatan pendapatan dan keuntungan responden. Selain itu usaha responden yang bergerak dalam sektor perdagangan menghasilkan pendapatan yang bersifat harian, sehingga perputaran uangnya lebih cepat.

Tabel 4 Perubahan pendapatan dan keuntungan setelah mendapatkan pembiayaan kategori debt financing

\begin{tabular}{|c|c|c|c|c|c|}
\hline \multirow[t]{2}{*}{ Indikator } & \multicolumn{5}{|c|}{ Debt Financing } \\
\hline & \multirow[t]{2}{*}{$\mathrm{N}$} & \multicolumn{3}{|c|}{ Rata-rata } & Probabilita \\
\hline & & Sebelum & Setelah & Selisih & \\
\hline Pendapata & 9 & $1.560 .566,6$ & $1.978 .000,0$ & $417.433,33$ & $0,000 * *$ \\
\hline n (Rp) & 0 & 7 & 0 & & \\
\hline Keuntunga & 9 & $288.768,89$ & $424.348,89$ & 135.580 & $0,000 * *$ \\
\hline $\mathrm{n}(\mathrm{Rp})$ & 0 & & & & \\
\hline terangan & & & $\tan$ & & \\
\hline Se & & $\begin{array}{l}\text { pedaan rata-r } \\
\text { biayaan }\end{array}$ & responden $\mathrm{s}$ & -sebelu & ndapatkan \\
\hline
\end{tabular}




\subsection{Faktor-Faktor yang Memengaruhi Pendapatan dan Keuntungan UMK setelah Mendapatkan Pembiayaan Kategori Debt Financing}

Tabel 5 menunjukan faktor-faktor yang berpengaruh signifikan terhadap pendapatan dan keuntungan usaha responden setelah pembiayaan. Hasil pengolahan data menunjukkan R-square sebesar 0.681 untuk pendapatan setelah pembiayaan yang artinya $68.1 \%$ keragaman nilai pendapatan setelah pembiayaan dapat dijelaskan oleh masing-masing variabel penjelas dalam model dan sisanya dijelaskan oleh variabel lain. Nilai Rsquare untuk keuntungan setelah pembiayaan adalah 0.352 yang artinya $35.2 \%$ keragaman nilai keuntungan setelah pembiayaan dapat dijelaskan oleh masing-masing variabel penjelas dalam model dan sisanya dijelaskan oleh variabel lain.

Tabel 5 Faktor-Faktor yang memengaruhi pendapatan dan keuntungan usaha responden setelah pembiayaan

\begin{tabular}{|c|c|c|c|c|}
\hline \multirow{2}{*}{ Variabel } & \multicolumn{2}{|c|}{ Pendapatan } & \multicolumn{2}{|c|}{ Keuntungan } \\
\hline & Koefisien & Probabilitas & Koefisien & Probabilitas \\
\hline Tenaga & 0,139 & $0,007 * * *$ & 0,159 & $0,002 * * *$ \\
\hline Kerja & & & & \\
\hline $\begin{array}{l}\text { Jumlah } \\
\text { Pembiayaan }\end{array}$ & 0,003 & $0,051^{*}$ & 0,002 & $0,071^{*}$ \\
\hline $\begin{array}{l}\text { Tingkat } \\
\text { Keuntungan }\end{array}$ & $-0,047$ & $0,000 * * *$ & $-0,008$ & $0,079 *$ \\
\hline $\begin{array}{l}\text { Dummy } \\
\text { Jenis }\end{array}$ & 0,342 & $0,012 * *$ & 0,355 & $0,009 * * *$ \\
\hline $\begin{array}{l}\text { Kelamin } \\
\text { Dummy } \\
\text { Pendidikan }\end{array}$ & 0,399 & $0,005 * * *$ & 0,359 & $0,011 * *$ \\
\hline $\mathrm{C}$ & 15,146 & 0,000 & 1,315 & 0,023 \\
\hline R-squared & 0,681 & & 0,352 & \\
\hline $\begin{array}{l}\text { Prob (F- } \\
\text { Statistik) }\end{array}$ & 0,000 & & 0,000 & \\
\hline eterangan: & $\begin{array}{l}* \text { ) signifika } \\
* * \text { ) signifik } \\
* * * \text { ) signifi }\end{array}$ & $\begin{array}{l}\text { la taraf ny } \\
\text { ada taraf n } \\
\text { pada taraf }\end{array}$ & $\begin{array}{l}10 \% \\
5 \% \\
1 \%\end{array}$ & \\
\hline
\end{tabular}

Variabel tenaga kerja berpengaruh positif terhadap pendapatan dengan koefisien pendugaan 0.139 pada taraf nyata $1 \%$ dan berpengaruh positif pada keuntungan dengan koefisien pendugaan 0.159 pada taraf nyata $1 \%$.

Jurnal Al-Muzara'ah Vol.4, No.2, 2016

(ISSN p: 2337-6333; e: 2355-4363) 
Hal ini menunjukkan bahwa semakin banyak tenaga kerja pada usaha responden maka akan semakin tinggi pendapatan dan keuntungan usaha responden. Peningkatan tenaga kerja sebesar 1 orang akan meningkatkan pendapatan usaha sebesar $0.151 \%$ per hari, ceteris paribus. Selain itu peningkatan tenaga kerja sebesar 1 orang juga akan meningkatkan keuntungan usaha sebesar $0.168 \%$ per hari, ceteris paribus. Peningkatan jumlah tenaga kerja dapat meningkatkan efisiensi waktu dalam kegiatan usaha perdagangan. Pelaku UMK yang memiliki tenaga kerja dapat melayani pembeli lebih banyak dan meningkatkan pemasaran produk.

Jumlah pembiayaan memiliki pengaruh positif terhadap pendapatan dan keuntungan. Koefisien pendugaan jumlah pembiayaan pada model pendapatan dan keuntungan masing-masing sebesar 0.003 dan 0.002 dengan taraf nyata yang sama yaitu $10 \%$. Artinya, peningkatan jumlah pembiayaan sebesar 1 rupiah akan meningkatkan pendapatan sebesar $0.003 \%$ dan keuntungan sebesar $0.002 \%$, ceteris paribus. Hasil ini menunjukan bahwa semakin besar jumlah pembiayaan yang diterima responden maka semakin besar juga pendapatan dan keuntungan yang dapat diperoleh setelah pembiayaan. Jumlah pembiayaan yang diberikan akan meningkatkan modal pelaku UMK. Peningkatan modal dapat membantu pelaku UMK dalam mengembangkan usahanya. Pelaku UMK yang berhasil mengembangkan usaha tentunya akan mengalami peningkatan pendapatan dan keuntungan.

Variabel tingkat keuntungan berpengaruh negatif terhadap pendapatan dengan koefisien pendugaan sebesar 0.047 pada taraf nyata $1 \%$ dan berpengaruh negatif pada keuntungan dengan koefisien pendugaan 0,008 pada taraf nyata $10 \%$. Artinya, peningkatan tingkat keuntungan $1 \%$ akan menurunkan pendapatan sebesar $0.046 \%$ dan menurunkan keuntungan sebesar $0.008 \%$, ceteris paribus. Tingkat keuntungan dapat meningkat apabila tingkat penjualan lebih besar dibandingkan biaya operasional atau dengan kata lain pelaku usaha berhasil menekan biaya operasional. Peningkatan tingkat keuntungan pada tingkat penjualan yang sama dan tanpa diikuti pengefisiensian biaya operasional justru akan berdampak pada penurunan pendapatan dan keuntungan. Selain itu, pelaku UMK yang menjadi responden berada dalam pasar yang memiliki persaingan tinggi, sehingga pedagang yang menetapkan tingkat keuntungan terlalu tinggi justru akan mengalami penurunan pendapatan dan keuntungan karena pembeli tentunya akan lebih memilih untuk membeli pada pedagang yang tidak menetapkan tingkat keuntungan terlalu tinggi. 
Dummy jenis kelamin berpengaruh positif terhadap pendapatan dan keuntungan. Pada model pendapatan dan keuntungan dummy jenis kelamin signifikan masing-masing pada taraf nyata $5 \%$ dan $1 \%$. Responden berjenis kelamin laki-laki memiliki pendapatan dan keuntungan lebih besar dibandingkan responden berjenis kelamin perempuan dengan selisih sebesar $0.342 \%$ untuk pendapatan dan $0.355 \%$ untuk keuntungan. Jumlah responden laki-laki yang lebih banyak dibandingkan responden perempuan dapat menjadi salah satu alasan responden laki-laki memperoleh pendapatan dan keuntungan yang lebih besar daripada responden perempuan. Selain itu mayoritas responden laki-laki menjadikan usahnya sebagai sumber pendapatan utama, sehingga dalam menjalankan usahanya responden laki-laki memiliki motivasi dan kemampuan yang lebih tinggi dibandingkan responden perempuan.

Dummy pendidikan berpengaruh positif terhadap pendapatan dan keuntungan dengan taraf nyata masing-masing sebesar $1 \%$ dan $5 \%$. Responden yang memiliki lama pendidikan 0 sampai 9 tahun memperoleh pendapatan dan keuntungan lebih besar daripada responden yang memiliki lama pendidikan diatas 9 tahun. Selisih pendapatan dan keuntungan antara responden yang lama pendidikannya 0 sampai 9 tahun dengan responden yang lama pendidikannya diatas 9 tahun adalah $0.393 \%$ dan $0.359 \%$. Hasil penelitian ini menunjukan bahwa lama pendidikan di atas 9 tahun tidak memiliki pengaruh terhadap perolehan pendapatan dan keuntungan responden. Pendapatan dan keuntungan usaha responden lebih dipengaruhi oleh pengalaman dan kemampuan responden dalam mengelola usahanya.

\section{Kesimpulan}

Pembiayaan kategori debt financing yang berdasarkan objek pertukaran barang dengan uang dalam hal ini mencakup pembiayaan murabahah dan ijarah dapat dijadikan pembiayaan yang ditujukan untuk memberikan bantuan modal kerja bagi UMK. Hal ini dikarenakan pembiayaan kategori debt financing memberikan pengaruh positif terhadap pendapatan dan keuntungan UMK, terbukti dari pendapatan dan keuntungan pelaku UMK yang meningkat setelah memperoleh pembiayaan debt financing. Tambahan modal dan tingkat marjin pembiayaan yang rendah serta adanya penyesuaian dengan kemampuan nasabah, membuat pelaku UMK dapat mengembangkan usahanya. Oleh karena itu BPRS Amanah Ummah 
diharapkan dapat meningkatkan jumlah pembiayaan debt financing bagi pelaku UMK.

Faktor-faktor yang memengaruhi pendapatan dan keuntungan UMK setelah mendapatkan pembiayaan debt financing yaitu tenaga kerja, jumlah pembiayaan, tingkat keuntungan, dummy jenis kelamin, dan dummy pendidikan. Tenaga kerja, jumlah pembiayaan, dummy jenis kelamin, dan dummy pendidikan berpengaruh positif terhadap pendapatan dan keuntungan setelah pembiayaan, sedangkan tingkat keuntungan berpengaruh negatif terhadap pendapatan dan keuntungan setelah pembiayaan. Oleh sebab itu pelaku UMK disarankan untuk menetapkan tingkat keuntungan yang tidak terlalu tinggi, karena tingkat keuntungan yang terlalu tinggi dapat menurunkan pendapatan dan keuntungan usaha mereka.

\section{Daftar Pustaka}

Ahiawodzi AK, Adade TC. 2012. Access to Credit and Growth of Small and Medium Scale Enterprises in the Ho Municipality of Ghana. British Journal of Economics, Finance, and Management Science. 6(2): 34-51.

Akoten JE, Sawada Y, Otsuka K. 2006. The Determinants of Credit Access and Its Impact on Micro and Small Enterprises: The Case of Garment Producers in Kenya. Economic Development and Cultural Change Journal. 54(4): 927-943.

Anggraeni L, Puspitasari H, Ayubbi SE, Wiliasih R. 2015. Akses UMKM Terhadap Pembiayaan Mikro Syariah dan Dampaknya Terhadap Perkembangan Usaha: Kasus BMT Tadbiirul Ummah, Kabupaten Bogor. Jurnal al-Muzara'ah. Vol.1(1).

Ascarya. 2008. Akad dan Produk Bank Syariah. Jakarta(ID): Raja Grafindo Persada.

[BPRS Amanah Ummah]. 2016. Komposisi Pembiayaan BPRS Amanah Ummah Tahun Anggaran 2013-2015. Bogor(ID): BPRS Amanah Ummah.

Dewi G. 2007. Aspek-aspek Hukum dalam Perbankan dan Pengasuransian Syari'ah di Indonesia. Jakarta(ID): Kencana.

Hakim AA. 2011. Fiqih Perbankan Syariah Transformasi Fiqih Muamalah ke dalam Peraturan Perundang-Undangan. Bandung (ID): PT. Refika Aditama.

[KEMENKOP] Kementerian Koperasi dan Usaha Kecil dan Menengah. 2010. Undang-Undang Republik Indonesia Nomor 20 Tahun 2008 
tentang Usaha Mikro, Kecil, dan Menengah. [katalog: Peraturan Undang-Undang tentang UMKM].

[KEMENKOP] Kementerian Koperasi dan Usaha Kecil dan Menengah. 2017. Perkembangan Data Usaha Mikro, Kecil, dan Menengah Tahun 2015, Unpublished..

Khan T, Ahmed H. 2001. Risk Management: An Analysis of Issues in Islamic Financial Industry. Islamic Research and Training Institute. 5(1). 61-79.

Kurniawan D. 2008. Uji T Berpasangan (Paired T-Test), Vienna (AT) : Foundation for Statistical Computing.

Muhammad. 2005. Bank Syariah Problem dan Prospek Perkembangan di Indonesia, Yogyakarta (ID): Graha Ilmu.

Nawawi I. 2012. Fikih Muamalah Klasik dan Kontemporer. Bogor (ID): Ghalia Indonesia.

[OJK] Otoritas Jasa Keuangan. 2016. Statistik Perbankan Syariah. Komposisi Pembiayaan yang Diberikan BPRS di Indonesia.

Rachman LH. 2014. Dampak Pembiayaan Syariah terhadap Profitabilitas Usaha Mikro pada Nasabah Bank Perkreditan Rakyat Syariah Harta Insan Karimah Kecamatan Ciledug Kota Tangerang. [skripsi]. Bogor (ID): Institut Pertanian Bogor.

Salamah SS. 2015. Analisis Pengaruh Pembiayaan Ijarah Terhadap Perkembangan UMKM (Studi Kasus BPR Syariah Amanah Ummah Leuwiliang Kabupaten Bogor). [skripsi]. Bogor (ID): Institut Pertanian Bogor.

Tambunan THT. 2009. UMKM di Indonesia, Jakarta (ID): Ghalia Indonesia.

Zuhaily W. 2001. Al-Fiqh Al-'Islami wa 'Adillatuh (Islamic Jurisprudence and Its Proofs). Damascus (SY): Dar Al-Fikr 